$$
\begin{aligned}
& \text { 研究ノート } \\
& \text { キュウリ, ピーマン果実の生育に伴う三，三の化学成分の変化 } \\
& \begin{array}{c}
\text { 高 間 総 子*, 福 田修 三*, 豊 巻 由美子*, } \\
\text { 豊 巻孝 子**, 斎藤 進* }
\end{array} \\
& * \text { 東京農業大学栄盖学科 }{ }^{* *} \text { 秋田経済大学家政学科 }
\end{aligned}
$$

\title{
Changes of Chemical Components of Cucumber and Sweet Pepper Fruits during Growth on the Tree
}

\author{
Fusako Takama*, Shuzo Fukuda*, Yumiko Toyomaki*, \\ Koko Toyomaki**, Susumu Saito* \\ * Department of Nutrition, Tokyo University of Agriculture \\ ** Department of Home Economy, Akita University of Economy
}

J. Jap. Soc. Food and Nutr., $26(5), 329 \sim 332$ (1973)

The cucumber and sweet pepper plants were cultured on the field at Toride, Ibaragi Prefecture to examine the variation of the quality and chemical components of their fruits during growth and to know the optimal time for marketing conditions. The cucumber fruits were picked up on the $2 \mathrm{nd}, 5$ th, 8 th and 10 th days after blossoming, and were analyzed on the respective day. The sweet pepper fruits were picked up for sample at 3 stages according to the fruit bigness. Quantitative analyses were made for moisture, ash, ascorbic acid and chlorophylls a and b.

The results are summarized as follows:

1) Cucumber flavor was good when the fruits were young, while sweet pepper flavor did not change during the growth of fruits.

2) The moisture content increased, while ash, ascorbic acid and chlorophyll contents decreased as the cucumber became bigger.

3) As the sweet pepper grew, the moisture content increased, ash and chlorophyll contents decreased, and ascorbic acid content increased.

From the above results, it may be concluded that the cucumber was good in quality when it was young, but sweet pepper showed similar quality during growth from the viewpoint of marketability.

(Received March 16, 1973)

従来, 蔬菜のビタミンCに関する報告 ${ }^{122)}$ は多く見ら れ，1972 年北川33は，ウリ科とフォイ科の果菜類の果実 中ビタミンCの分布, 同生育期別含量差異を詳細に検討 報告している。また著者らは水耕栽培において, 生育中 のトマト果実の還元型ビタミンCとカロチノイド系色素 の経時的消長を報告()してきた。

ところで市場性からみて, 熟期が速やかで, 熱度, 形 推が商品価値を左右するキニウリと，比較的に熟期が長
く, 熟度, 形態等の商品価値要来の安定しているピーマ ンについての，収穫適期を成分品質上より娭討した報告 は少ない。

そこで著者らは，市場性と収穫適期を調べる目的で， 開花後結実してから可食期に至るキュウリとピーマンに ついて, 還元型ビタミンC，クロロフィルなど二，三の 化学成分および品質について経時的变化を検討してみ た。 
奏験材料および実験方法

\section{1. 実験材料}

茨城県取手の闻湯でキュウリ，ピーマンを下記のよう に露地栽培を行ない，採取，供試した。1 回の分析に 6 〜 8 個体を用いた。

1）キニウリ 2 月中旬に播種した品種「さつきみど り」を用い， 6 月12日から 7 月10日にかけて, 開花後 2 日，5日 (Fig. 1, A)，8日 (Fig. 1，B) および 10 日
の 4 期に採取し, 当日分析した。市場には 5 日から 8 日 のものが多く出回っている。

2) ピーマン1月中旬に播種した品種「にしき」を 用い, 7 月 11 日から 24 日にかけて, 重量と形の大きさ を考虑して果実生育第 1 期（Fig. 2, A)，2 期および 3 期（Fig. 2，B）の3期に採取し，当日分析に供した。 ピーマン果実の生育の様相が複雑である゙ ため,このよ うな 3 期の分け方をした。果実生長第 3 期を通常使用し ている。

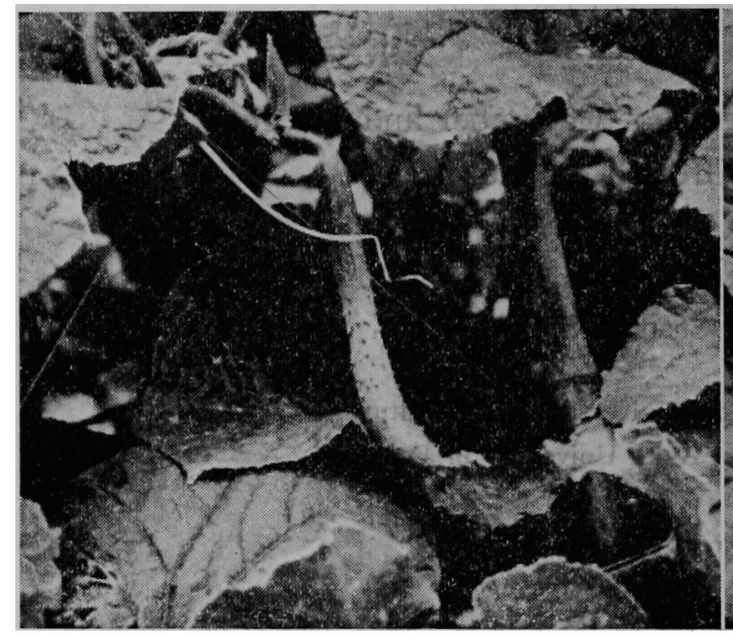

A

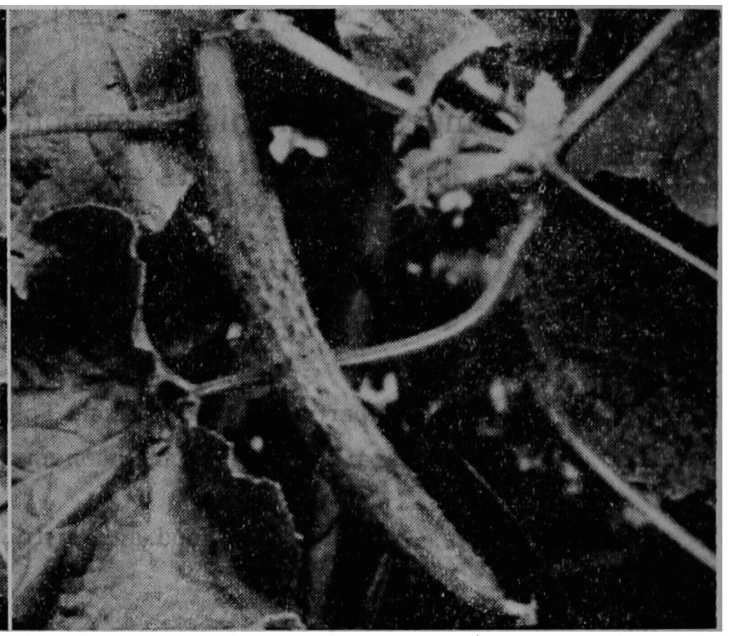

B

Fig. 1. The aspects of cucumber fruits during growth cucumber fruits were picked off for sample on the 2 nd, 5 th, 8 th and 10 th days after blossoming.

A: the 5 th day after blossoming, B: the 8 th day after blossoming.

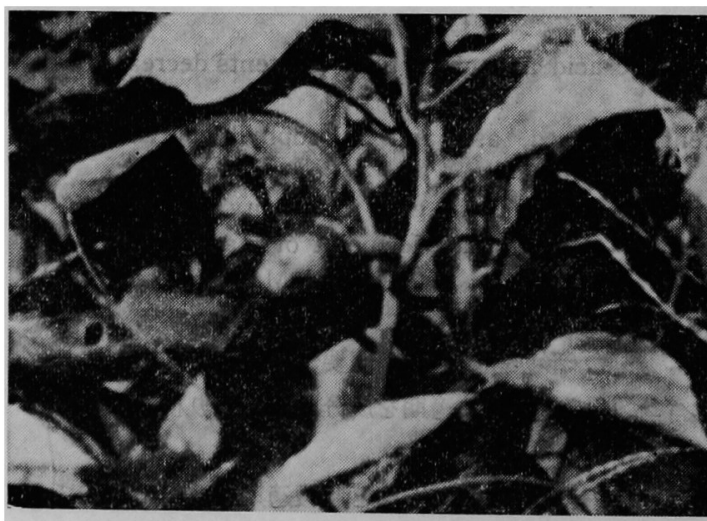

A

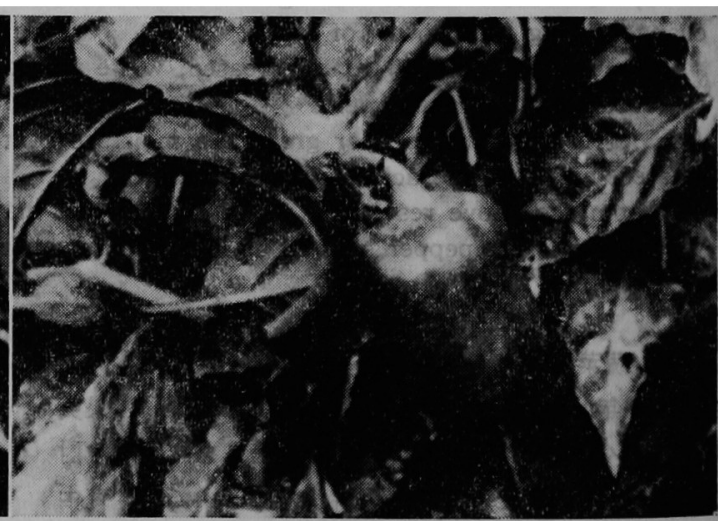

B

Fig. 2. The aspects of sweet pepper fruits during growth sweet pepper fruits were picked off for sampling on the 3 stages by the difference of bigness.

A : the 1st stage of bigness, $\mathrm{B}$ : the $3 \mathrm{rd}$ stage of bigness. 


\section{2. 实酸方法}

1）形状，色沢，品質試験 実験材料の項で述べた時 期にまず形状を長さ，直径，果重について調へた。ま た，色沢は表面色の变化，品質は風味に主眼点をおいて 調へたた。

2）生育別成分試験 たてに四つ割りして対称片を用 いた。なおピーマンは種子を除いた。

水分：ケット式赤外線水分計によった。

灰分：550 600 $\mathrm{C}$ にて灰化して定量した。

逥元型ビタミンC：インドフェノール法によった。 クロロフィル：さきに有色野菜のクロロフィルについ

て行なっだ) と同様, A.O.A.C. 法7)によってク ロロフィルを抽出し，エチルエーテル溶液の 660 $\mathrm{m} \mu$ と $642.5 \mathrm{~m} \mu$ における吸光度を求め, Comar の式によってクロロフィルa，bを算出した。

実験結果および考察

実跧結果は，Table 1，2 と示すようであった。

1）形態は，生育に伴ってキュウリ，ピーマンとも比 例的な伸びをみせた。キュウリ果皮は開花後 5 日目まで 泊色を帯びた緑色であるが，しだいに粶色の濃さを増 し10日目のすのは袭厚緑色であった。幼果ほど香りが高 く品筫がすぐれ，生育するにつれて風味が劣ってきた。 ピーマンの表面色は成育するにつれて緑色がしたいに薄 くなったが，風味の点では生育に伴う変化は認められな かった。ピーマンはキュウリほと風味を尊重する料理法 をとらないので,生育中の価値が変わらないと思われた。
2）キュウリの㵱元型ビタミンCは，生育するにつれ て減少した。これは北川の報告とも一致するところであ り，また著者らが別に行なった実験です同一時期キュウ リ生育盛んな先端部の摆元型ビタミンC含有量が高く, このことから生育の旺盛な生理作用が比較的活発である ためと推定される。ピーマン果実の還元型ビタミンCは 増加を示した。

3）水分含量は生育に伴い増加した。形態が大きくな るにつれて細胞の膨圧維持8) のため根から水分を吸収す るためと推定される。

4）灰分量は減少した。灰分の生成量が形態の大きさ 増加に伴わないためと思われる。

5）キュウリおよびピーマンのクロロフィル含量は， クロロフィルa，bともに減少した。キュウリ，ピーマ ンともに過熟時はクロロフィル減少, カロチノイド増加 のものであるし，とくにキュウリは果肉の白色部をる供 試しているため，皮部に比し果肉が増加したためである う。またピーマン果実生育第 3 期は,クロロフィルaが $18.93 \mathrm{mg} / 100 \mathrm{~g}, \mathrm{~b}$ が $12.02 \mathrm{mg} / 100 \mathrm{~g}$ とする篠”) の報 告と似た傾向を示した。

以上より，植物の科の相違や可食部位のちがう蔬菜の 特徵が見いだされ，このことより果菜類生育期における 市場性最適期が存在すると思われた。

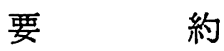

キュウリとピーマンを茨城県取手の直場にて露地栽培 を行ない，果実を生育期別沉キュウリは開花後 $2 ， 5$ ，

Table 1. Changes of the size and some chemical components of the cucumber fruit during growth.

\begin{tabular}{cccccccc}
\hline \hline \multirow{2}{*}{$\begin{array}{c}\text { Stage of } \\
\text { Growth }\end{array}$} & $\begin{array}{c}\text { Average } \\
\text { weight of } \\
\text { a fruit } \\
(\mathrm{g})\end{array}$ & $\begin{array}{c}\text { Average } \\
\text { length of } \\
\text { a fruit } \\
(\mathrm{cm})\end{array}$ & $\begin{array}{c}\text { Moisture } \\
(\%)\end{array}$ & $\begin{array}{c}\text { Ash } \\
(\%)\end{array}$ & $\begin{array}{c}\text { Ascorbic } \\
\text { acid } \\
(\mathrm{mg} \%)\end{array}$ & \multicolumn{2}{c}{ Chlorophyll (mg \%) } \\
\cline { 8 - 10 } 2 nd Day & 1.8 & 5.49 & 92.5 & 1.17 & 37.67 & 34.0 & 28.1 \\
5 th Day & 20.2 & 13.58 & 93.4 & 0.96 & 24.57 & 29.8 & 23.4 \\
8 th Day & 127.5 & 23.36 & 94.8 & 0.77 & 16.33 & 25.5 & 21.1 \\
10 th Day & 353.1 & 32.71 & 95.3 & 0.57 & 12.65 & 19.7 & 18.4 \\
\hline \hline
\end{tabular}

Table 2. Changes of the size and some chemical components of the sweet pepper fruit during growth.

\begin{tabular}{|c|c|c|c|c|c|c|c|c|}
\hline \multirow{2}{*}{$\begin{array}{l}\text { Stage of } \\
\text { Growth }\end{array}$} & \multirow{2}{*}{$\begin{array}{l}\text { Average } \\
\text { weight of } \\
\text { a fruit } \\
\text { (g) }\end{array}$} & \multirow{2}{*}{$\begin{array}{l}\text { Average } \\
\text { length of } \\
\text { a fruit } \\
(\mathrm{cm})\end{array}$} & \multirow{2}{*}{$\begin{array}{c}\text { Diameter } \\
\text { of a fruit } \\
\quad(\mathrm{cm})\end{array}$} & \multirow{2}{*}{$\begin{array}{c}\text { Moisture } \\
(\%)\end{array}$} & \multirow{2}{*}{$\begin{array}{l}\text { Ash } \\
(\%)\end{array}$} & \multirow{2}{*}{$\begin{array}{c}\text { Ascorbic } \\
\text { acid } \\
(\mathrm{mg} \%)\end{array}$} & \multicolumn{2}{|c|}{ Chlorophyll (mg \%) } \\
\hline & & & & & & & a & $\mathrm{b}$ \\
\hline 1 st Stage & 6.8 & 2.93 & 2.65 & 91.7 & 0.72 & 48.29 & 24.9 & 17.2 \\
\hline 2 nd Stage & 27.5 & 4.63 & 4.30 & 92.1 & 0.33 & 50.41 & 22.2 & 16.8 \\
\hline 3 rd Stage & 73.1 & 6.24 & 5.90 & 92.9 & 0.33 & 73.01 & 14.4 & 10.3 \\
\hline
\end{tabular}


8 おび10日目に, またピーマンは形態から果実生育 第 1，2および 3 期に採取し，品質，成分を調へた。そ の結果, キュウリは色沢が濃厚となり, 品質はやや低 下, 水分量が増加, 還元型ビタミンC, クロロフィルが 隇少した。

ピーマンは色沢が薄れるが, 品質の変化は認められ す, 水分含量が増加, 灰分, クロロフィルが減少, 還元 型ビタミンCが増加することが認められた。以上のこと からキュウリは生育前期の幼果ほど風味良好でもあり成 分上から価值が高く, それにくらペピーマンは生育全期 を通して前者ほど, 品質成分の価値が变わらないと思わ れた。

終わりに,クロロフィル定量についてご指導賜わった 食品分析センターの斎藤 実氏, 須田浩行氏, 上野順士

氏に感謝申し上げます。

\section{女 城}

1）菅原友太：患・園芸作物のビタミン C に関する 研究 (1957), 须賢堂

2) 斎藤 進，狩野総子：農大農集報，13,68(1968)

3) 北川雪江：栄堆と食粠， 25，436 (1972)

4) 斉藤 進, 狩野総子：農大農集報, 14, 237 (1969)

5）丸川慎三：ピーマシ作型とつくり方, 43(1970), 農山漁村文化協会

6) 斎藤 進, 高間総子, 田中なな子, 杉㥓順子 : 栄養誌, 28, 233 (1970)

7) A.O.A.C., 115 (1965)

8) Bonner, Galston : 植物の生理, 高宮 䈆, 小 合安之訳, 87 (1971), 岩波書店

9）篠 图彦, 速水 決：栄盖研報，40（1960） (昭和 48 年 3 月 16 日受理) 